JRPB, Vol. 7, No. 2, September 2019, Hal. 249-255

DOI: $10.29303 /$ jrpb.v7i2.144

ISSN 2301-8119, e-ISSN 2443-1354

Tersedia online di http://jrpb.unram.ac.id/

\title{
RANCANG BANGUN DAN UJI KINERJA MESIN PERAJANG TEMBAKAU MESIN PERAJANG TEMBAKAU SEMI MEKANIS SISTEM KAYUH
}

\author{
Design of Semi-Mechanical Tobacco Slicer Machine with Paddle Type \\ Sandra Malin Sutan ${ }^{1}$,Yoga Aditya Pratama ${ }^{1 *}$, Gunomo Djoyowasito ${ }^{1}$, \\ Ary Mustofa Ahmad ${ }^{1}$ \\ ${ }^{1}$ Jurusan Keteknikan Pertanian, Fakultas Teknologi Pertanian, \\ Universitas Brawijaya, Jl. Veteran, Malang 65145 \\ Email $^{*}$ : yogaadityapratama87@gmail.com
}

Diterima: Juli 2019

Disetujui: September 2019

\begin{abstract}
Tobacco is a very promising export commodity for Indonesia. With a high selling price, tobacco can improve the economic level of the tobacco farming community. Problems that are often faced in the tobacco processing process are long and less efficient crafting processes. Therefore, a tool to support an effective and efficient crafting process is necessary. The making of tools is done in Malang creative art welding workshop and tool testing is carried out in the power laboratory and agricultural machinery. The purpose of making this tool is to make the semi-mechanical tobacco chopper system paddle and test the performance of the chopper machine. The working principle of this machine is that the blade shaft that is connected to the pedaling pedal will rotate when the pedal is moved and will slice the leaves of tobacco that enter through the leaf input section. From the results of engine performance tests that have been made obtained the value of engine efficiency is $94 \%$ and the average capacity of $21.92 \mathrm{~kg} /$ hour and the power needed by the engine is $0.228 \mathrm{HP}$
\end{abstract}

Keywords: engine power, paddle system, slicer, tobacco

\begin{abstract}
ABSTRAK
Tembakau merupakan tanaman komoditas ekspor yang sangat menjanjikan bagi Indonesia. Dengan harga jual yang tinggi, tembakau dapat meningkatkan taraf perekonomian masyarakat petani tembakau. Masalah yang sering dihadapi dalam proses pengolahan tembakau adalah proses perajangan yang lama dan kurang efisien. Oleh karena itu, diperlukan suatu alat guna menunjang proses perajangan yang efektif dan efisien. Pembuatan alat dilakukan di bengkel las Art Creative Malang dan pengujian alat dilakukan di Laboratorium Daya dan Mesin Pertanian. Tujuan dari penelitian ini adalah membuat alat perajang tembakau semi mekanis sistem kayuh dan menguji kinerja dari mesin perajang terebut. Prinsip kerja dari mesin ini, yaitu poros pisau yang tersambung
\end{abstract}


pada pedal pengayuh akan berputar ketika pedal digerakkan dan akan mengiris daun tembakau yang masuk melalui bagian penginputan daun. Dari hasil uji kinerja mesin yang telah dibuat didapatkan nilai efisiensi mesin, yaitu 94\% dan kapasitas rata-rata 21,92 $\mathrm{Kg} / \mathrm{jam}$ dan daya yang dibutuhkan mesin sebesar 0,228 HP.

Kata kunci: daya mesin, perajang, sistem kayuh, tembakau

\section{PENDAHULUAN}

\section{Latar Belakang}

Tanaman tembakau merupakan tanaman tropis yang dapat hidup pada rentang iklim yang luas. Karena responnya netral terhadap panjang hari. (Suwarto, dkk., 2014). Tembakau merupakan tanaman komoditas ekspor yang sangat menjanjikan bagi Indonesia. Tembakau Indonesia merupakan jenis tembakau terbaik yang beredar di pasar dunia. Daun tembakau mempunyai beberapa varietas yang umum dijumpai di Indonesia antara lain seperti tembakau deli, tembakau deli, tembakau temanggung, tembakau Vorstelanden, tembakau Madura, tembakau besuki dan tembakau Lombok timur (Siregar dan Zuliyanti, 2016)

Dewasa ini, pemanfaatan daun tembakau lebih ditekankan pada bahan baku utama untuk pembuatan rokok. Sebenarnya banyak produk-produk lain yang dapat dihasilkan dari daun tembakau ini. Seperti halnya bioinsektisida. Bio insektisida dari bahan baku nikotin daun tembakau ini lebih ramah lingkungkan disbanding dengan insektisida berbahan baku DDT. Petani dapat lebih diuntungkan dengan adanya bioinsektisida ini karena akan menurunkan biaya produksi dan biaya operasional pertanian disamping terhindarnya tanaman produksi dari hama serangga (Paramartha dan Lazuardi, 2013)

Dalam pengolahan daun tembakau, kendala yang umum dihadapi yaitu proses perajangan yang memerlukan waktu lama dan kurang menunjang sisi keamanan dari perajang tembakau. Hal ini karena alat yang digunakan masih sederhana. Dimana pada umumnya perajangan masih menggunakan pisau perajang konvensional dan tatakan kayu sebagai tempat dari daun tembakau (Djumali, 2011).

Berdasarkan permasalahan tersebut maka dibuat sebuah mesin perajang tembakau semi mekanis menggunakan sistem kayuh yang mudah digunakan. Untuk mengoperasi mesin perajang tembakau semi mekanis ini digunakan daya dari operator untuk memutar poros dari pisau perajang. Dimana antara poros pisau dan penggerak dari operator dihubungkan oleh rantai dan gir sproket dengan rasio 44:1. Untuk memaksimalkan hasil rajangan digunakan 2 buah mata pisau perajang yang terpasang pada poros.

\section{METODE PENELITIAN}

\section{Alat dan Bahan}

Beberapa alat yang digunakan dalam penelitian ini antara lain las listrik, gerinda tangan, bor tangan, palu rivet, meteran, dan penggaris siku.

Adapun bahan yang digunakan dalam penelitian ini, yaitu mesin tembakau, paku rivet, timbangan, besi plat, besi profil siku, dan roda gigi.

\section{Metode}

Pembuatan mesin dilakukan pada bulan Juni - Juli 2018 bertempat di bengkel las Art Creative Malang dan pengujian mesin dilakukan pada bulan Agustus 2018 dan bertempat di Laboratorium Daya dan Mesin Pertanian Jurusan Keteknikan Pertanian Fakultas Teknologi Pertanian Universitas Brawijaya. Adapun tahapan penelitian ini, yaitu (1) merancang desain mesin, (2) Pembuatan bagian mesin perajang, (3) Perakitan bagian mesin perajang, dan (4) pengujian mesin perajang tembakau. Desain rancangan mesin 
perajang tembakau dapat dilihat pada Gambar 1.

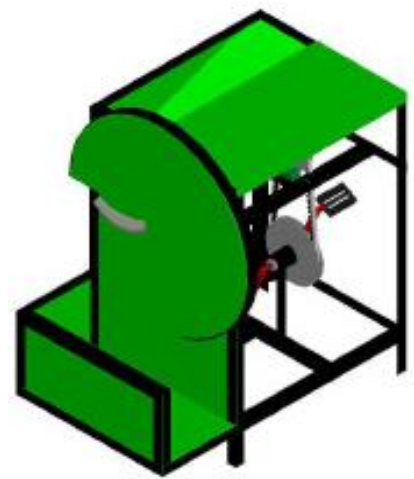

Gambar 1. Desain Mesin Perajang Tembakau Semi Mekanis Sistem Kayuh

Desain pisau perajang tembakau dibuat melengkung dengan sudut potong $10^{\circ}$ dengan harapan dapat menghasilkan potongan yang lebih halus dan mengurangi memar yang disebabkan ketika pisau berputar dan memotong gulungan daun tembakau. Desain pisau perajang dapat dilihat pada Gambar 2.

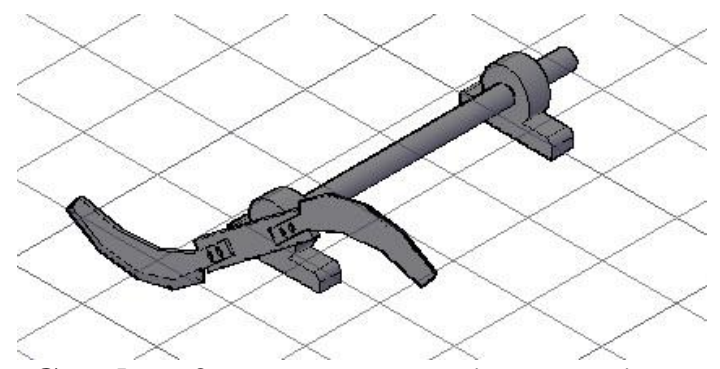

Gambar 2. Pemasangan pisau perajang pada poros

Pengujian yang dilakukan pada mesin ini bertujuan untuk menguji kelayakan fungsi alat ketika beroperasi. Pengujian dilakukan untuk mendapatkan nilai efisiensi, kapasitas, dan daya yang dibutuhkan dari mesin perajang. Adapun untuk pengujian dilakukan dengan merajang daun tembakau yang telah digulung sebanyak 5 kali ulangan dengan massa yang sama pada tiap ulangannya.
1. Massa jenis Tembakau

Massa jenis dari daun tembakau yang dipakai pada pengujian dihitung menggunakan persamaan 1 .

$\rho=\frac{m}{v}$

Dimana:

$\rho=$ Massa Jenis Tembakau $\left(\mathrm{kg} / \mathrm{cm}^{3}\right)$

$m=$ Massa tembakau $(\mathrm{kg})$

$v=$ Volume Gulungan daun tembakau $\left(\mathrm{cm}^{3}\right)$

2. Kapasitas Aktual

Kapasitas Aktual Mesin Perajang Tembakau dihitung menggunakan persamaan 2 .

$K a=\frac{W p}{t}$

Dimana:

$\mathrm{Ka}=$ Kapasitas Aktual Perajangan (kg/menit)

$\mathrm{Wp}=$ Berat Tembakau yang keluar dari input perajang $(\mathrm{kg})$

$\mathrm{t}=$ Waktu yang diperlukan untuk merajang tembakau (menit)

3. Kapasitas Teoritis

Kapasitas teoritis mesin perajang tembakau dihitung menggunakan persamaan 3 .

$m f=\rho f \times A t \times L c \times \lambda k \times N c$

Dimana:

$\mathrm{m}_{\mathrm{f}} \quad=$ Kapasitas Teoritis $(\mathrm{kg} / \mathrm{s})$

$\rho=$ Densitas Bahan $\left(\mathrm{kg} / \mathrm{m}^{3}\right)$

$\mathrm{A}_{\mathrm{t}} \quad=$ Luas Area Perajangan $\left(\mathrm{cm}^{2}\right)$

$\mathrm{L}_{\mathrm{c}} \quad=$ Lebar Rajangan (mm)

$\lambda=$ Jumlah Pisau Perajang

$\mathrm{N} \quad=$ Kecepatan Putar Pisau rpm)

\section{Efisiensi Mesin}

Efisiensi mesin perajang tembakau dihitung menggunakan persamaan 4 .

$\mathrm{E}_{\mathrm{f}}=\frac{K a}{K t} \times 100 \%$

Dimana:

$\mathrm{E}_{\mathrm{f}} \quad=$ Efisiensi mesin perajang (\%),

$\mathrm{Ka}=$ Kapasitas Aktual (kg/jam),

$\mathrm{Kt}=$ Kapasitas Perajangan Teoritis $(\mathrm{kg} / \mathrm{jam})$

\section{Gaya Potong Pisau}

Gaya potong yang dihasilkan pisau perajang dapat dihitung menggunakan persamaan 5 .

$F=\tau \times A$ 
Dimana:

$$
\begin{array}{ll}
F & =\text { Gaya Potong Pisau }(\mathrm{kg}) \\
\tau & =\text { Tegangan Geser Tembakau }\left(\mathrm{kg} / \mathrm{cm}^{2}\right) \\
A & =\text { Luas Penampang }\left(\mathrm{cm}^{2}\right)
\end{array}
$$

\section{Massa tembakau yang terpotong}

Massa tembakau yang terpotong selama putaran pisau dapat dihitung menggunakan persamaan 6 .

$m=\rho \times V$.

Dimana:

$\mathrm{M} \quad=$ massa tembakau yang terpotong $(\mathrm{kg})$

$\rho \quad=$ massa jenis tembakau $\left(\mathrm{kg} / \mathrm{cm}^{3}\right)$

$V \quad=$ Volume tembakau terpotong pisau $\left(\mathrm{cm}^{3}\right)$

\section{Putaran pisau perajang}

Putaran pisau perajang yang terjadi diukur menggunakan tachometer pada putaran gir pedal kemudian dihitung menggunakan persamaan:

$N 1 \times Z 1=N 2 \times Z 2$.

Dimana:

$\mathrm{N} 1=$ Putaran gir pada pedal pengayuh (rpm)

$\mathrm{N} 2=$ Putaran gir pisau perajang $(\mathrm{rpm})$

$\mathrm{Z} 1$ = Jumlah gigi pada gir pedal pengayuh

Z2 = Jumlah gigi pada poros pemutar pisau rajangan

8. Daya yang dibutuhkan mesin

Daya yang dibutuhkan mesin untuk beroperasi dapat dihitung menggunakan persamaan:

$\mathrm{P}=\frac{T x n}{5252}$

Dimana:

$\mathrm{P}=$ Daya mesin yang dibutuhkan $(\mathrm{HP})$

$\mathrm{n}=$ kecepatan putar $(\mathrm{rpm})$

$\mathrm{T}=$ Torsi (N.m)

\section{HASIL DAN PEMBAHASAN}

\section{Hasil Rancang Bangun Mesin}

Perancangan mesin perajang tembakau semi mekanis sistem kayuh ini menggunakan software AutoCad 2017. Perancangan mesin perajang tembakau semi mekanis sistem kayuh ini dilakukan dengan pendekatan struktural dan fungsional. Rancangan struktural digunakan untuk mengetahui komponen dan dimensi secara detail dari setiap komponen tersebut pada model yang dibuat. Rancangan fungsional digunakan untuk mengetahui fungsi dari setiap komponen model alat. Hasil penerapan dari rancangan yang telah dilakukan dapat dilihat pada Gambar 3.

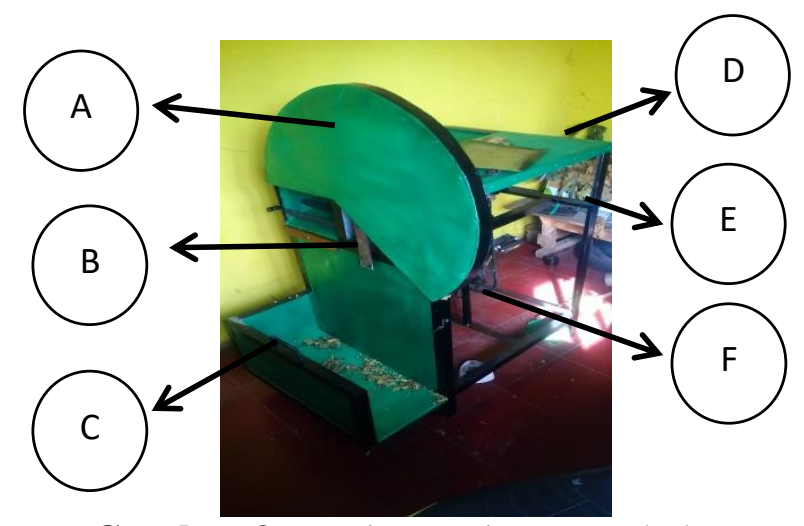

Gambar 3. Mesin Perajang Tembakau Semi Mekanis Sistem Kayuh

Adapun bagian dan fungsi dari masing masing bagian adalah sebagai berikut: (a) penutup pisau yang berfungsi untuk melindungi operator dari pisau yang berputar, (b) pisau yang berfungsi untuk merajang daun tembakau, (c) penampung yang berfungsi untuk menampung daun tembakau yang telah dirajang, (d) meja daun tembakau yang berfungsi sebagai tatakan daun tembakau sebelum dimasukkan ke input perajangan, (e) kerangka mesin yang berfungsi sebagai penyangga mesin, (f) transmisi gir sproket dan rantai yang berfungsi sebagai penyalur daya dari operator ke poros putar pisau.

\section{Hasil Uji Kinerja Mesin}

Dari hasil pengujian mesin perajang tembakau semi mekanis sistem kayuh dengan 5 kali pengulangan menggunakan daun tembakau dengan massa yang sama didapatkan massa tembakau yang keluar dari output perajang berjumlah $1,82 \mathrm{Kg}$. Hasil uji kinerja mesin perajang tembakau dapat dilihat pada Tabel 1. 
Tabel 1. Hasil Uji Kinerja Mesin Perajang Tembakau

\begin{tabular}{cccc}
\hline Ulangan & $\begin{array}{c}\text { Massa } \\
(\text { Kg) }\end{array}$ & $\begin{array}{c}\text { Putaran } \\
\text { Roda Gigi } \\
(\mathbf{r p m})\end{array}$ & $\begin{array}{c}\text { Massa } \\
\text { Tembakau } \\
\text { yang keluar } \\
(\mathbf{k g})\end{array}$ \\
\hline 1 & 2 & 86 & 0,42 \\
2 & 2 & 82 & 0,39 \\
3 & 2 & 79 & 0,34 \\
4 & 2 & 80 & 0,36 \\
5 & 2 & 76 & 0,31 \\
\hline Jumlah & & & 1,82 \\
\hline
\end{tabular}

Dari Tabel 1 terlihat bahwa rpm yang terukur pada tachometer tidak konstan. Hal ini disebabkan karena daya yang diberikan oleh operator tidak sama pada putaran pedal. Makin besar rpm atau putaran pisau maka massa tembakau yang dikeluarkan akan semakin besar. Hal ini disebabkan karena semakin besar rpmm mata pisau akan lebih sering memotong tembakau. Menurut Mursidi (2015), faktor yang mempengaruhi kapasitas kerja mesin adalah kemampuan mentransfer daya pada perajangan dan sifat fisik bahan (kekerasan) bahan yang dipakai sebagai bahan uji.

Dari kelima ulangan pengujian kapasitas didapatkan besar kapasitas rata rata perajang adalah sebesar 0,364 $\mathrm{Kg} / \mathrm{menit}$ atau sebesar $21,84 \mathrm{~kg} / \mathrm{jam}$. Tembakau yang digunakan pada uji kinerja mesin ini memiliki densitas sebesar 1,132 x $10^{-3} \mathrm{~kg} / \mathrm{cm}^{3}$. Pengukuran densitas bahan dilakukan dengan perbandingan massa gulungan tembakau dengan volume gulungan tembakau tersebut. Besar densitas tembakau pada umumnya sebesar $3,57 \times 10^{-4} \mathrm{Kg} / \mathrm{cm}^{3}$ (Pitrandjalisari, 2014). Hasil rajangan daun tembakau dapat dilihat pada gambar 4. Hasil rajangan memiliki tebal yang bervariasi atau tidak seragam. Rata rata tebal rajangan daun tembakau berkisar antara $1-2 \mathrm{~mm}$.

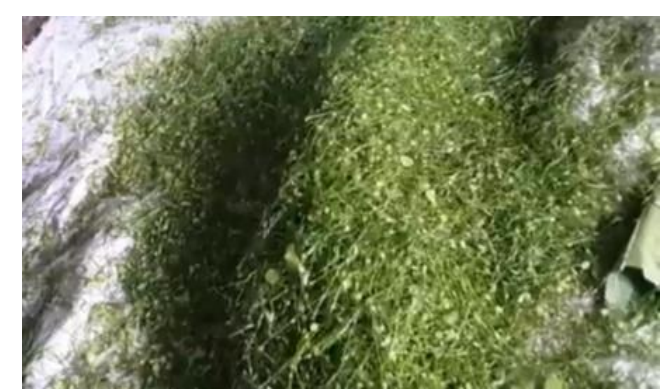

Gambar 4. Hasil Rajangan Daun

Tembakau

Hasil Rajangan yang tidak seragam dapat disebabkan karena kecepatan penginputan daun ke perajang tidak sama dengan kecepatan putar pisau perajang. Hasil pengukuran ketebalan rajangan daun tembakau dapat dilihat pada Tabel 2.

Data sebaran ketebalan rajangan tembakau terlihat bervariasi pada tiap ulangannya. Dapat disimpulkan bahwa ketebalan rajangan tembakau yang dihasilkan masih bervariasi. Hal ini dikarenakan kecepatan penginputan daun ke dalam mulut potong tidak selaras dengan kecepatan putar pisau yang dihasilkan. Menurut Nurdaib (2019) kecepatan putar pisau akan mempengaruhi

Tabel 2. Ketebalan Hasil Rajangan daun Tembakau

\begin{tabular}{cccccc}
\hline \multirow{2}{*}{ Sampel } & \multicolumn{5}{c}{ Ulangan } \\
\cline { 2 - 6 } & I & II & III & IV & V \\
\hline 1 & 2 & 1 & 3.5 & 2 & 1.5 \\
2 & 1.2 & 2.5 & 1.2 & 1.5 & 1 \\
3 & 3.1 & 1.5 & 1.5 & 2.1 & 1 \\
4 & 1.8 & 1.3 & 0.5 & 1.4 & 1.5 \\
5 & 1.5 & 1.2 & 1 & 2.1 & 1.7 \\
\hline Rata- Rata & 1.92 & 1.5 & 1.54 & 1.82 & 1.34 \\
$X^{2}$ & 3.6864 & 2.25 & 2.3716 & 3.3124 & 1.7956 \\
Std Dev & \pm 0.725948 & \pm 0.587367 & \pm 1.154556 & \pm 0.342053 & \pm 0.320936 \\
\hline
\end{tabular}


besar cacahan atau rajangan yang dihasilkan. Semakin cepat putaran pisau maka hasil cacahan akan semakin kecil/tipis. Sebaran data ketebalan rajangan daun tembakau dapat dilihat pada Gambar 5.

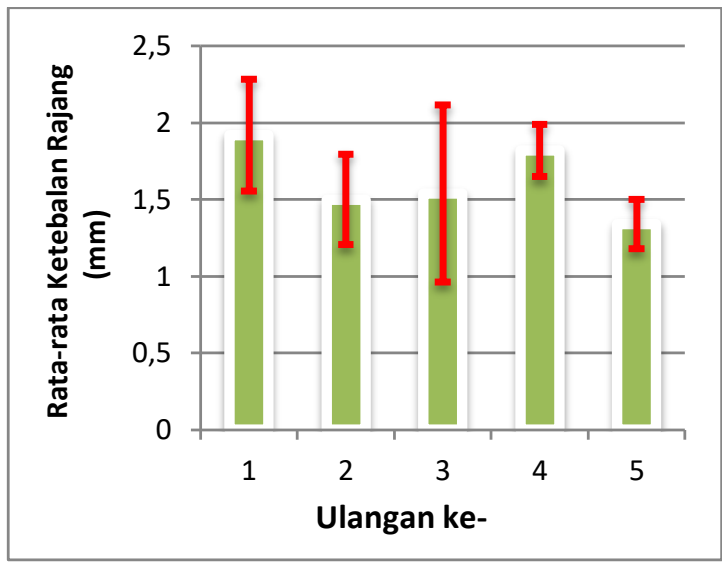

Gambar 5. Standar Deviasi Keseragaman Tebal Rajangan Daun Tembakau

Menurut Albaha (2011), besarnya jumlah rajangan tembakau yang dihasilkan oleh mesin berbanding lurus dengan jumlah putaran pisau mesin perajang. Maka dari itu jumlah tembakau yang keluar tiap pengujian bervariasi tergantung pada kecepatan putar mesin yang dioperasikan oleh operator.

\section{Efisiensi Mesin Perajang}

Efisiensi merupakan hasil perbandingan antara kapasitas actual mesin perajang tembakau dengan kapasitas teoritis dengan nilai berupa persentase. Efisiensi dapat dihitung menggunakan persamaan 4. Hasil dari perhitungan didapatkan efisiensi senilai $94 \%$ dengan nilai kapasitas aktual sebesar 21,92 kg/jam dan kapasitas teoritis mesin sekitar 23,22 $\mathrm{kg} / \mathrm{jam}$. Faktor yang mempengaruhi kerja mesin adalah sifat fisik bahan (kekerasan) bahan dan perbedaan kemampuan mentransfer daya pada perajangan (Mursidi, 2015)

\section{Daya yang dibutuhkan Mesin Perajang}

Berdasarkan perhitungan yang telah dilakukan dengan persamaan 8 , daya yang dibutuhkan mesin untuk dapat beroperasi senilai 0,228 HP dengan torsi yang dihasilkan sebesar 7,45 N.m dan besar putaran pisau 161,2 rpm. Gaya potong yang dihasilkan pisau perajang ketika mengiris daun tembakau sebesar 32,39 N. Menurut Tirtosastro dan Musolaeni (2015), besar tenaga yang digunakan manusia dalam beraktivitas berbeda beda sesuai dengan beban kerja yang dilakukan. Beban kerja manusia dapat digolongan menjadi 3 (tiga), yaitu kerja ringan dengan tingkat penggunakan tenaga $0,15 \mathrm{HP}-0,3 \mathrm{HP}$, kerja sedang dengan tingkat penggunaan energi 0,3 HP - 0,5 HP dan kerja berat dengan tingkat penggunaan energi sebesar 0,5 HP sampai 0,8 HP. Dengan daya yang dibutuhkan operator untuk mengoperasikan mesin cukup rendah, mesin ini tidak akan membebani kerja yang dilakukan oleh operator.

\section{KESIMPULAN DAN SARAN}

\section{Kesimpulan}

Dari penelitian rancang bangun mesin perajang tembakau semi mekanis tipe kayuh dapat disimpulkan bahwa:

1. Dihasilkan mesin perajang semi mekanis sitem kayuh dengan dimensi keseluruhan mesin yaitu sebesar 700 $\mathrm{mm} \times 600 \mathrm{~mm}$ x $900 \mathrm{~mm}$

2. Besar nilai efisiensi mesin perajang tembakau semi mekanis sistem kayuh diketahui sebesar $94 \%$

3. Daya yang dibutuhkan untuk mengoperasikan mesin perajang tembakau semi mekanis adalah sebesar 0,228 HP

\section{Saran}

Adapun saran yang disimpulkan setelah dilakukan penelitian rancang bangun mesin perajang tembakau semi mekanis tipe kayuh ini antara lain, yaitu:

1. Perlu adanya perbaikan rancangan untuk menyeimbangkan antara putaran pisau potong dan masukan daun ke 
input perajang agar ketebalan hasil rajangan

2. Perlu adanya modifikasi pada bagian penginputan daun untuk memperlancar proses masuknya daun ke bagian pisau perajang

\section{DAFTAR PUSTAKA}

Albaha, F. 2011. Proses Pembuatan Rangka pada Mesin Perajang Daun Tembakau. Yogyakarta; Fakultas Teknik Unversitas Negeri Yogyakarta

Djumali. 2011. Karakter Agronomi yang Berpengaruh Terhadap Hasil dan Mutu Rajangan Kering Tembakau Temanggung. Malang; Buletin Tanaman Tembakau, serat dan Minyak Industri 3(1) Balai Penelitian Tembakau dan Serat

Mursidi, R. 2015. Desain Perajang Serbaguna dengan Tipe Blade Sliding dan Sistem Transfer Tenaga Semi Mekanis dan Mekanis. Prosiding Seminar Agroindustri dan Lokakarya Nasional FKPT-TPI Program Studi TIP-UTM Universitas Sriwijaya

Nurdaib. 2019. Analisa Kemiringan Sudut Mata Pisau Mesin Pencacah Daun Kering Terhadap Pencacahan Untuk
Kompos Organik. Kediri; Universitas Nusantara PGRI Kediri

Paramartha, D., dan Lazuardi, Y. 2013. Pemanfaatan Nikotin untuk Memproduksi Bio Insektisida dengan Bio Ekstrasi Cair. Semarang; Jurnal Teknik Kimia dan Industri Universitas Dipoegoro

Pitrandjalisari, V. 2014. Perancangan Mesin Perajang Tembakau dengan 3

Mata Pisau Pada Kapasitas 120 Kg/jam. Malang; Jurnal Widya Teknika Vol.22 No.1; Maret 2014

Siregar, A., dan Zuliyanti. 2016. Literasi Inventarisasi Hama dan Penyakit Tembakau Deli Di Perkebunan Sumatera Utara. Medan: Jurnal Pertanian Tropik Vol 3 No. 3 Fakultas Pertanian Universitas Sumatera Utara

Suwarto, Y. Octavianty, dan S. Hermawati. 2014. Top 15 Tanaman Perkebunan. Penebar Swadaya. Jakarta.

Tirtosastro, S., dan Musolaeni, W. 2015. Penanganan Panen Dan Pasca Panen Tembakau dikabupaten Bojonegoro. Malang; Jurnal Buana Sains Vol 15 No. 2.155-164 Universitas Tribhuwana. Tunggadewi. 